\title{
A Comparative Analysis of E-cigarette Users and State-Specific Prevalence Change in the United States Between 2017 and 2018
}

\author{
Tarang Parekh ${ }^{1}$, Rupak Desai ${ }^{2}$ \\ 1. Epidemiology and Public Health, George Mason University, Fairfax, USA 2. Cardiology, Atlanta Veterans Affairs \\ Medical Center, Decatur, USA
}

Corresponding author: Tarang Parekh, drtarangparekh@gmail.com

\section{Abstract \\ Introduction}

Despite states' regulatory efforts, e-cigarettes are gaining popularity, which poses a public health concern. The study objective is to compare demographic and state prevalence changes in e-cigarette use from 2017 to 2018.

\section{Methods}

A retrospective analysis was conducted using publicly available data from the Behavioral Risk Factor Surveillance System survey (2017-2018). The prevalence of current e-cigarette use was analyzed with direct age-adjustment based on the 2010 United States Census population.

\section{Results}

The overall use of e-cigarettes increased from $4.3 \%$ in 2017 to $5.4 \%$ in 2018 . Although most demographics reported increased prevalence from 2017 to 2018, the most significant change was observed in younger adults (18-24), males, Hispanics, college graduates, non-smokers, marijuana non-users, and heavy alcoholics. Oklahoma (9.8\%), Hawaii (7.8\%), Arkansas (7.7\%), and Colorado (7.3\%) greater prevalence in 2018. Significant inclining prevalence was observed in Alaska, Connecticut, and Massachusetts, while Illinois reported a sharp decline. California, the District of Columbia, and Puerto Rico consistently reported the lowest prevalence. Idaho, Maine, Michigan, North Dakota, and Oregon are transitioning to a higher prevalence of e-cigarette use from 2017 to 2018.

\section{Conclusion}

The rising prevalence of e-cigarettes across demographics warrants a holistic approach to behavioural change interventions, health awareness and education, and regulatory efforts.

Review began 12/04/2020 Review ended 12/08/2020 Published 12/14/2020

(c) Copyright 2020 Parekh et al. This is an open access article distributed under the terms of the Creative Commons Attribution License CC-BY 4.0, which permits unrestricted use, distribution, and reproduction in any medium, provided the original author and source are credited.
Categories: Preventive Medicine, Public Health, Epidemiology/Public Health

Keywords: e-cigarette, vaping, smoking, marijuana, state prevalence, e-cigarette laws, demographics, electronic cigarette

\section{Introduction}

The most frequently published data on substance use in recent times remain pertinent to electronic cigarettes (vaping) and cannabis (marijuana) use in addition to tobacco smoking and alcohol abuse among young $[1,2]$. The paucity of evidence proposing a clear risk and benefits of mainly using e-cigarettes merits for contemporary data to screen population remaining at higher risk of polysubstance use with potentially greater health risk. We sought to assess the age-adjusted prevalence of current e-cigarette use between 2017 and 2018 in a diverse subset of the population. Concomitantly we report comparative state-specific prevalence in 2017 and 2018 with state-wise effective dates on laws related to e-cigarettes.

\section{Materials And Methods}

A retrospective analysis was conducted using the publicly available data from the Behavioral Risk Factor Surveillance System (BRFSS) survey (2017-2018). The BRFSS is the largest telephone-based annual population survey of United States adult residents conducted by the Centers for Disease Control and Prevention (CDC) on health-related risk behaviours, chronic health conditions, and preventive services utilization [3]. The prevalence of current e-cigarette use was analyzed with direct age-adjustment based on the 2010 US Census population. Data were collected from main and all available optional modules with information on e-cigarette use. Current e-cigarette use was assessed using the following two BRFSS questions: (1) "Have you ever used an e-cigarette or other electronic vaping products, even just one time, in your entire life?” and (2) “Do you now use e-cigarettes or other vaping products every day, some days, or not 


\begin{tabular}{|c|c|c|c|}
\hline \multirow[t]{2}{*}{ Characteristics } & \multicolumn{2}{|c|}{$\begin{array}{l}\text { Age-adjusted prevalence of current e-cigarette use, \% (95\% } \\
\mathrm{Cl})\end{array}$} & \multirow{2}{*}{$\begin{array}{l}\text { Annual Percentage Change (APC), } \\
\% \\
2017-2018\end{array}$} \\
\hline & $2017(n=570,589)$ & $2018(n=360,096)$ & \\
\hline Overall & $4.3(4.2-4.5)$ & $5.4(5.2-5.6)$ & 25.6 \\
\hline \multicolumn{4}{|l|}{ Age Group ${ }^{a}$} \\
\hline 18-24 year & $9.6(8.9-10.3)$ & $14.1(13.1-15.1)$ & 46.9 \\
\hline 25-34 year & $6.6(6.9-7.1)$ & $7.7(7.1-8.4)$ & 16.7 \\
\hline 25- 44 year & $4.4(4.1-4.8)$ & $5.3(4.8-5.9)$ & 20.5 \\
\hline 45- 54 year & $3.1(2.8-3.4)$ & $3.6(3.2-3.9)$ & 16.1 \\
\hline 55- 64 year & $2.5(2.2-2.7)$ & $2.7(2.3-3.0)$ & 8.0 \\
\hline 65 or above year & $0.9(0.8-1.0)$ & $1.0(0.8-1.1)$ & 11.1 \\
\hline \multicolumn{4}{|l|}{ Sex } \\
\hline Male & $5.4(5.1-5.6)$ & $6.8(6.4-7.1)$ & 25.9 \\
\hline Female & $3.2(3.1-3.4)$ & $4.0(3.8-4.3)$ & 25.0 \\
\hline \multicolumn{4}{|l|}{ Race } \\
\hline White, $\mathrm{NH}$ & $5.5(5.3-5.7)$ & $6.7(6.4-7.0)$ & 21.8 \\
\hline Black, NH & $3.0(2.6-3.4)$ & $3.3(2.9-3.8)$ & 10.0 \\
\hline Other, NH & $3.6(3.2-4.1)$ & $4.9(4.2-5.7)$ & 36.1 \\
\hline Hispanic & $2.2(1.9-2.5)$ & $3.4(2.9-3.9)$ & 54.6 \\
\hline \multicolumn{4}{|c|}{ Gender Orientation b } \\
\hline Cisgender & $4.1(3.9-4.4)$ & $5.8(5.5-6.1)$ & 41.5 \\
\hline Transgender & $6.1(3.4-8.9)$ & $10.3(6.9-13.8)$ & 68.9 \\
\hline \multicolumn{4}{|c|}{ Sexual Orientation ${ }^{\text {b }}$} \\
\hline Straight & $4.1(3.8-4.3)$ & $5.7(5.4-6.0)$ & 39.0 \\
\hline Lesbian/Gay & $6.3(4.6-8.0)$ & $8.6(6.7-10.5)$ & 36.5 \\
\hline Bisexual & $6.9(5.3-8.5)$ & $8.9(7.3-10.5)$ & 29.0 \\
\hline
\end{tabular}




\section{Cureus}

\begin{tabular}{|c|c|c|c|}
\hline Other & $5.7(2.3-9.2)$ & $7.1(4.8-9.3)$ & 24.6 \\
\hline \multicolumn{4}{|l|}{ Education } \\
\hline Less than High School & $4.5(4.0-4.9)$ & $5.2(4.6-5.9)$ & 15.6 \\
\hline High School Graduate & $5.4(5.1-5.7)$ & $6.6(6.1-7.0)$ & 22.2 \\
\hline Some College & $5.1(4.8-5.4)$ & $6.4(5.9-6.8)$ & 25.5 \\
\hline College Graduate & $2.1(1.9-2.4)$ & $3.3(3.0-3.6)$ & 57.1 \\
\hline \multicolumn{4}{|l|}{ Marital Status } \\
\hline Married & $3.1(2.9-3.4)$ & $3.7(3.3-4.2)$ & 19.4 \\
\hline Unmarried & $4.9(4.6-5.3)$ & $6.4(6.0-6.9)$ & 30.6 \\
\hline Divorced/Widow/Separated & $6.5(5.6-7.4)$ & $8.3(6.9-9.7)$ & 27.7 \\
\hline \multicolumn{4}{|l|}{ Employment Status } \\
\hline Unemployed & $6.0(5.3-6.7)$ & $6.7(5.5-7.9)$ & 11.7 \\
\hline Employed & $4.3(4.1-4.5)$ & $5.5(5.2-5.8)$ & 27.9 \\
\hline Retired & $3.2(1.1-5.4)$ & $3.2(1.6-4.8)$ & 0.0 \\
\hline Student/Home Maker & $3.0(2.7-3.4)$ & $3.7(3.2-4.2)$ & 23.3 \\
\hline Unable to Work & $6.9(6.0-7.8)$ & $9.4(7.5-11.2)$ & 36.2 \\
\hline \multicolumn{4}{|l|}{ Cigarette Smoking } \\
\hline Never Smoker & $1.3(1.1-1.4)$ & $1.9(1.7-2.0)$ & 46.2 \\
\hline Former Smoker & $8.7(8.0-9.3)$ & $12.2(11.3-13.0)$ & 40.2 \\
\hline Current Smoker & $13.4(12.7-14.1)$ & $15.1(14.2-16.0)$ & 12.7 \\
\hline \multicolumn{4}{|l|}{ Heavy Alcohol Use ${ }^{c}$} \\
\hline No & $4.1(3.9-4.2)$ & $5.0(4.7-5.2)$ & 21.9 \\
\hline Yes & $7.6(6.8-8.4)$ & $10.5(9.5-11.5)$ & 38.2 \\
\hline \multicolumn{4}{|l|}{ Smokeless Tobacco Use ${ }^{d}$} \\
\hline Never & $4.1(3.9-4.3)$ & $5.2(4.9-5.4)$ & 26.8 \\
\hline Sometimes & $11.5(9.6-13.4)$ & $14.7(12.4-17.1)$ & 27.8 \\
\hline Regular & $7.6(5.9-9.3)$ & $8.1(6.2-10.0)$ & 6.6 \\
\hline \multicolumn{4}{|l|}{ Current Marijuana Use ${ }^{b}$} \\
\hline No & $2.4(2.1-2.8)$ & $3.5(3.1-3.9)$ & 45.8 \\
\hline Yes & $9.3(7.3-11.2)$ & $11.1(9.6-12.6)$ & 19.4 \\
\hline \multicolumn{4}{|l|}{ Physically Active ${ }^{\mathrm{e}}$} \\
\hline No & $4.8(4.4-5.1)$ & $5.5(5.0-6.0)$ & 14.6 \\
\hline Yes & $4.1(4.0-4.3)$ & $5.3(5.1-5.5)$ & 29.3 \\
\hline \multicolumn{4}{|l|}{ Body Mass Index (BMI) } \\
\hline Underweight & $7.4(5.8-9.0)$ & $6.2(4.8-7.5)$ & -16.2 \\
\hline Normal & $4.4(4.1-4.6)$ & $5.6(5.2-5.9)$ & 27.3 \\
\hline Overweight & $4.5(4.2-4.8)$ & $5.3(4.9-5.7)$ & 17.8 \\
\hline Obese & $4.7(4.3-5.0)$ & $5.6(5.1-6.1)$ & 19.2 \\
\hline Pregnancy Status & & & \\
\hline
\end{tabular}




\section{Cureus}

$\begin{array}{llll}\text { Non-pregnant } & 3.0(2.6-3.5) & 4.3(3.0-5.6) & 43.3 \\ \text { Pregnant } & 2.3(0.1-4.7) & 1.8(1.0-2.6) & -21.7 \\ \text { Veteran } & & & \\ \text { No } & 4.2(4.0-4.4) & 5.2(5.0-5.4) & 23.8 \\ \text { Yes } & 6.0(5.4-6.7) & 8.4(7.0-9.7) & 40.0\end{array}$

TABLE 1: Age-adjusted prevalence and prevalence percentage change in current e-cigarette use among adults aged 18-64 years, Behavioral Risk Factor Surveillance System, 2017-2018

a Unadjusted weighted prevalence reported.

${ }^{b}$ Data not available for the entire BRFSS data years. Reported prevalence is calculated from the secondary data analyses using respected subpopulation characteristics.

${ }^{c}$ Heavy alcohol use reported for males having five or more drinks on one occasion and females having four or more drinks on one occasion at least once in a month.

d Smokeless tobacco use is calculated if an individual reported current use of chewing tobacco, snuff, or snus every day or some days.

e Physically active participants were identified if individuals reported any physical activity or exercises (ex. running, calisthenics, golf, gardening, or walking) other than their regular job last month.

Table 2 showed the state-specific prevalence of e-cigarette use and effective dates for relevant e-cigarette laws. While the majority of states have passed e-cigarette related laws very recently that limits the ability to assess the effectiveness of such laws, the table provides critical information for future study references.

\begin{tabular}{|c|c|c|c|c|c|c|c|}
\hline State & $\begin{array}{l}\text { Prevalence, } \\
\% \text { (2017) }\end{array}$ & $\begin{array}{l}\text { Prevalence, } \\
\% \text { (2018) }\end{array}$ & $\begin{array}{l}\text { Annual } \\
\text { Percentage } \\
\text { Change, \% }\end{array}$ & $\begin{array}{l}\text { Laws on } \\
\text { Taxing E- } \\
\text { cigs }^{\text {a }}\end{array}$ & $\begin{array}{l}\text { Laws on E-cig } \\
\text { Retail Licensure } \\
\text { b }\end{array}$ & $\begin{array}{l}\text { Laws on Prohibiting } \\
\text { indoor e-smoking }\end{array}$ & $\begin{array}{l}\text { Laws on sales } \\
\text { restriction to age } \\
<21^{\text {d }}\end{array}$ \\
\hline Alabama & 5.2 & 6.4 & 18.8 & & 8/1/2019 & & \\
\hline Alaska & 3.2 & 6.2 & 48.4 & & 1/1/2019 & & \\
\hline Arizona & 5.5 & 3.1 & -77.4 & & & & \\
\hline Arkansas & 5.8 & 7.7 & 24.7 & & 5/1/2015 & & 12/31/2021 \\
\hline California & 3.1 & 3.9 & 20.5 & 4/1/2017 & 1/1/2017 & 6/9/2016 & 6/9/2016 \\
\hline Colorado & 5.4 & 7.3 & 26.0 & & & 7/1/2019 & \\
\hline Connecticut & 3.5 & 6.1 & 42.6 & $10 / 1 / 2019$ & 3/1/2016 & & 10/1/2019 \\
\hline Delaware & 5.2 & 5.2 & 0.0 & 1/1/2018 & & 10/5/2015 & 7/16/2019 \\
\hline $\begin{array}{l}\text { District of } \\
\text { Columbia }\end{array}$ & 2.2 & 2.0 & -10.0 & 10/1/2015 & 10/22/2015 & 11/18/2016 & $11 / 29 / 2016$ \\
\hline Florida & 4.8 & 7.0 & 31.4 & & & & \\
\hline Georgia & 4.4 & 5.6 & 21.4 & & & & \\
\hline Hawaii & 5.0 & 7.8 & 35.9 & & 7/1/2018 & 1/1/2016 & 1/1/2016 \\
\hline Idaho & 4.7 & 6.5 & 27.7 & & 7/1/2020 & & \\
\hline Illinois & 4.9 & 2.4 & -104.2 & 7/1/2019 & & & 7/1/2019 \\
\hline Indiana & 6.1 & 7.1 & 14.1 & & 7/1/2015 & & \\
\hline lowa & 4.2 & 5.7 & 26.3 & & 7/1/2014 & & \\
\hline Kansas & 4.6 & 5.8 & 20.7 & 7/1/2017 & 7/1/2012 & & \\
\hline Kentucky & 6.1 & 6.8 & 10.3 & & & & \\
\hline
\end{tabular}




\section{Cureus}

\begin{tabular}{|c|c|c|c|c|c|c|c|}
\hline Louisiana & 4.5 & 6.1 & 26.2 & 7/1/2015 & $5 / 28 / 2014$ & & \\
\hline Maine & 4.6 & 6.2 & 25.8 & $1 / 2 / 2020$ & 11/1/2017 & & 7/1/2021 \\
\hline Maryland & 3.4 & 5.0 & 32.0 & & 10/1/2017 & & 10/1/2019 \\
\hline Massachusetts & 3.5 & 5.9 & 40.7 & 6/1/2020 & $6 / 1 / 2020$ & 7/27/2018 & $12 / 31 / 2021$ \\
\hline Michigan & 4.9 & 6.4 & 23.4 & & & & \\
\hline Minnesota & 3.8 & 5.4 & 29.6 & 8/1/2010 & $8 / 1 / 2014$ & & \\
\hline Mississippi & 5.1 & 5.9 & 13.6 & & & & \\
\hline Missouri & 5.3 & 6.2 & 14.5 & & 10/10/2014 & & \\
\hline Montana & 4.4 & 5.2 & 15.4 & & 1/1/2016 & & \\
\hline Nebraska & 3.8 & 5.8 & 34.5 & & $1 / 1 / 2020$ & & \\
\hline Nevada & 5.6 & 6.0 & 6.7 & $1 / 1 / 2020$ & $1 / 1 / 2020$ & & \\
\hline $\begin{array}{l}\text { New } \\
\text { Hampshire }\end{array}$ & 5.0 & 5.4 & 7.4 & $1 / 1 / 2020$ & $7 / 1 / 2019$ & & \\
\hline New Jersey & 4.8 & N/A & N/A & 9/29/2018 & 11/1/2019 & 7/11/2010 & 11/1/2017 \\
\hline New Mexico & 5.1 & 4.5 & -13.3 & $7 / 1 / 2019$ & $1 / 1 / 2021$ & 6/14/2019 & \\
\hline New York & 4.0 & 5.6 & 28.6 & 12/1/2019 & 12/1/2019 & 11/22/2017 & $11 / 13 / 2019$ \\
\hline North Carolina & 5.0 & 5.7 & 12.3 & 6/1/2015 & & & \\
\hline North Dakota & 4.0 & 6.0 & 33.3 & & & 12/6/2012 & \\
\hline Ohio & 5.7 & 5.9 & 3.4 & 10/1/2019 & 7/18/2019 & & 10/17/2022 \\
\hline Oklahoma & 6.9 & 9.8 & 29.6 & & & & \\
\hline Oregon & 4.7 & 6.0 & 21.7 & & & 1/1/2016 & $1 / 1 / 2018$ \\
\hline Pennsylvania & 5.1 & N/A & N/A & 7/13/2016 & 7/13/2016 & & 7/1/2020 \\
\hline Rhode Island & 5.1 & 5.8 & 12.1 & & $1 / 1 / 2015$ & 7/1/2018 & \\
\hline South Carolina & 4.3 & 3.2 & -34.4 & & & & \\
\hline South Dakota & 4.3 & 4.8 & 10.4 & & & 7/1/2019 & \\
\hline Tennessee & 6.2 & 6.5 & 4.6 & & & & \\
\hline Texas & 4.6 & 5.6 & 17.9 & & 10/1/2015 & & $8 / 31 / 2022$ \\
\hline Utah & 4.7 & 5.3 & 11.3 & 7/1/2020 & 7/1/2015 & $5 / 8 / 2012$ & 7/1/2021 \\
\hline Vermont & 3.4 & 4.1 & 17.1 & 7/1/2029 & 7/1/2013 & 7/1/2016 & 9/1/2019 \\
\hline Virginia & 5.1 & 5.3 & 3.8 & & & & $7 / 1 / 2019$ \\
\hline Washington & 4.4 & N/A & N/A & 10/1/2019 & 6/28/2016 & & $1 / 1 / 2020$ \\
\hline West Virginia & 6.3 & N/A & N/A & 7/1/2016 & & & \\
\hline Wisconsin & 4.5 & 5.1 & 11.8 & 10/1/2019 & & & \\
\hline Wyoming & 6.0 & 7.0 & 14.3 & 7/1/2020 & 7/1/2020 & & 7/1/2020 \\
\hline Guam & 5.8 & 5.0 & -16.0 & & & & $1 / 1 / 2018$ \\
\hline Puerto Rico & 1.2 & 1.5 & 20.0 & 4/29/2017 & & 4/11/2011 & \\
\hline Virgin Islands & N/A & N/A & N/A & $10 / 15 / 2014^{\star}$ & & & \\
\hline
\end{tabular}

TABLE 2: Annual Prevalence change in e-cigarette use by states, and effective dates for ecigarette related laws 


\title{
Cureus
}

\author{
a State laws effective data for any excise tax levied on e-cigarettes. \\ ${ }^{b}$ Effective date from when an individual is required to obtain a license or permit before conducting the business of selling e-cigarettes over the \\ counter. \\ ${ }^{c}$ Effective date from when state laws prohibit smoking in indoor areas of private worksites, restaurants, and bars. \\ ${ }^{d}$ Effective date for required minimum 21 years of age by a state that an individual must reach before vendors can legally sell e-cigarettes to an \\ individual. \\ * Date when state law was enacted. The effective date is not available.
}

Overall, the majority of states reported increased prevalence in 2018 than in 2017 (Figure 1). In 2018, the highest prevalence was observed in Oklahoma (9.8\%), Hawaii (7.8\%), Arkansas (7.7\%), Colorado (7.3\%), Indiana (7.1\%), Wyoming (7.0\%), and Florida (7.0\%). The lowest prevalence (<4\%) was reported in Puerto Rico, District of Columbia, Illinois, Arizona, and California. Of states, Alaska (APC 48.4\%), Connecticut (APC 42.6\%), and Massachusetts (APC 40.7\%) reported significant inclining, while Illinois (APC - 104.2\%) and Arizona (APC - 77.4\%) reported a major declining prevalence of e-cigarettes from 2017 to 2018. Idaho, Maine, Michigan, North Dakota, and Oregon states are transitioning to a higher prevalence of e-cigarette use from 2017 to 2018.
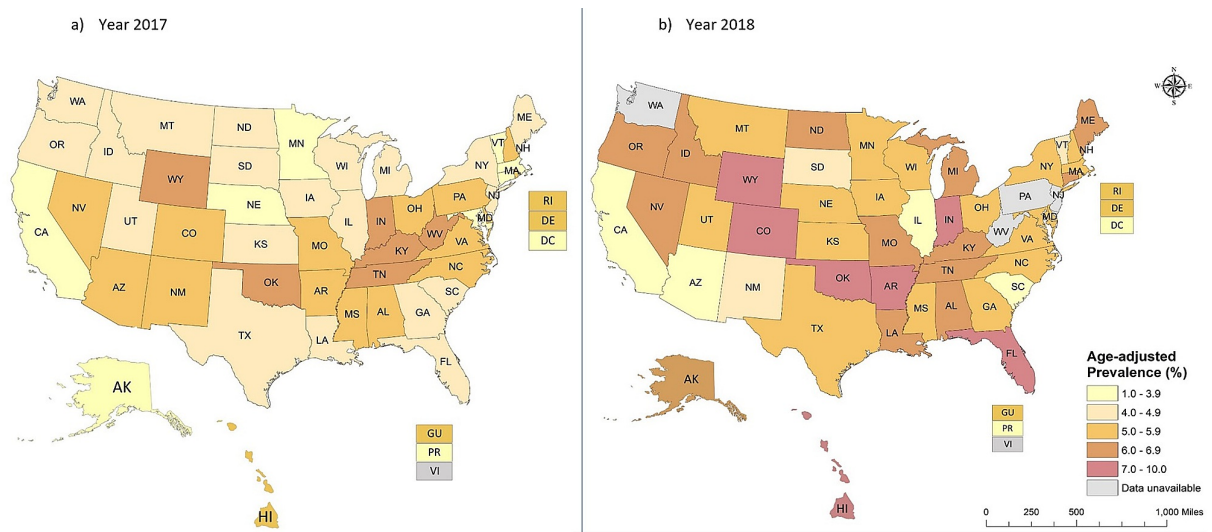

\section{FIGURE 1: State-specific e-cigarette prevalence}

A: Year 2017

B: Year 2018

\section{Discussion}

Recent reports on the prevalence of e-cigarette use showed varied rates in the United States adult population representing diverse geographic, ethnic, and socioeconomic strata [1]. Consistently, we observed Caucasians dominating the study cohort; however, all age, sex, and racial/ethnic groups reported increased e-cig use during the study period. The most pronounced increase was noted among the young (18-24 years) participants, males, and Hispanics. Education and employment status also showed an impact on the frequency of e-cigarettes. Low education among participants (less than high school, $4.5 \%$ \& $5.2 \%$ ) and those who were either unable to work (6.9\% \& 9.4\%) or were unemployed (6\% \& 6.7\%) reported a high frequency of using e-cigarettes. Expectedly, current cigarette smoking was associated with a higher frequency (15.1\%) of concomitant e-cigarette smoking as compared to former cigarette smoking. This finding is corroborative of earlier reports suggesting concerning behavioural patterns in youth indicating polysubstance use. While the prevalence of e-cigarette use during the last two years was also evident in heavy alcohol users, marijuana users, current smokers, the greatest inclining was observed among marijuana non-users and nonsmokers. This rising frequency of e-cigarettes use is concerning as numerous reports starting suggested potential severe adverse healthcare effects of using e-cigarettes, including cardio-cerebrovascular and lunginjury $[4,10,11]$.

Furthermore, we found interesting differences in terms of the state-wise prevalence of e-cigarette use during the study period. Looking at higher incremental use of e-cigarettes in states including Arkansas, Colorado, Florida, Indiana, Oklahoma, and Wyoming, call for attention from policymakers especially any conclusive evidence showing beneficial effects of e-cigarettes over combustible cigarette smoking over a long period whereas numerous reports suggesting acute healthcare effects in young individuals using e- 
cigarettes $[4,10,12]$. Reassuringly, a few states including Arizona, Illinois, New Mexico, and South Carolina, showed a steep decline in the use of e-cigarettes which could be hypothesized due to improved awareness regarding the ill effects of vaping among the general public and physicians. However, it would be interesting to see if these states would be able to continue to control the vaping epidemic until clear, conclusive evidence and guidelines endorse the use of e-cigarette use and its benefits over combustible cigarette use. Interestingly, California, the District of Columbia, and Puerto Rico have shown consistently lower prevalence during 2017-18. One possible explanation could be laws taxing e-cigarettes and strict e-smoking regulations, including required retail licensure imposed before the study period [6,7,13]. In contrast, states such as Idaho, Michigan, North Dakota, and Oregon without requirements for retail licensure and excise tax showed increasing prevalence from 2017 to 2018. Future studies should look at the longitudinal effects of states' policy efforts in regulating e-cigarette use and changing prevalence in the population.

Although the survey design is limited in terms of self-reported information and identifying the duration, mode, and sequential use of the e-cigarette, combustible cigarette, and marijuana, it remains important to highlight the alarming rate at which polysubstance abuse has been increasing since the last few years. While it is early to conclude the relationship between e-cigarette, smoking, and marijuana, it is essential to assess ongoing trends between 2019 and 2020 especially with enormous scientific evidence highlighting the severe health impacts of both substances.

\section{Conclusions}

The study provides essential information on a recent increase in the overall use of e-cigarette and concomitant rising prevalence of polysubstance use. The most pronounced rise in e-cigarette use between 2017 and 2018 was noted in young, male, and Hispanic survey participants. A few states like California and the District of Columbia showed an encouraging decline in e-cigarette use. In contrast, states like Arkansas, Colorado, and Florida showed a steep rise and call for attention from physicians and policymakers to spread awareness among young adults about the adverse effects of e-cigarette use. Whether state regulation efforts have any influence on e-cigarette prevalence is inconclusive, these findings open a door for debate on reevaluating states' current smoking policies and public health efforts.

\section{Additional Information \\ Disclosures}

Human subjects: Consent was obtained by all participants in this study. Animal subjects: All authors have confirmed that this study did not involve animal subjects or tissue. Conflicts of interest: In compliance with the ICMJE uniform disclosure form, all authors declare the following: Payment/services info: All authors have declared that no financial support was received from any organization for the submitted work. Financial relationships: All authors have declared that they have no financial relationships at present or within the previous three years with any organizations that might have an interest in the submitted work. Other relationships: All authors have declared that there are no other relationships or activities that could appear to have influenced the submitted work.

\section{References}

1. Mirbolouk M, Charkhchi P, Kianoush S, et al.: Prevalence and distribution of e-cigarette use among U.S. adults: behavioral risk factor surveillance system, 2016. Ann Intern Med. 2018, 169:429-438. 10.7326/M173440

2. Parekh T, Pemmasani S, Desai R: Marijuana use among young adults (18-44 years of age) and risk of stroke: a behavioral risk factor surveillance system survey analysis. Stroke. 2020, 51:308-310. 10.1161/STROKEAHA.119.027828

3. CDC: about BRFSS . (2014). Accessed: November, 2020: https://www.cdc.gov/brfss/about/index.htm.

4. Parekh T, Pemmasani S, Desai R: Risk of stroke with e-cigarette and combustible cigarette use in young adults. Am J Prev Med. 2020, 58:446-452. 10.1016/j.amepre.2019.10.008

5. Gimm G, Parekh T, Rossheim ME: Prevalence and risk factors of e-cigarette use among working-age adults with and without disabilities in 2017-2018 (IN PRESS). Disabil Health J. 2020, 10.1016/j.dhjo.2020.101048

6. CDC: state system e-cigarette legislation - tax. (2020). Accessed: March 02, 2020: https://chronicdata.cdc.gov/Legislation/CDC-STATE-System-E-Cigarette-Legislation-Tax/kwbr-syv2/data.

7. CDC: smoke free indoor air laws, including e-cigarette . (2020). Accessed: March 02, 2020: https://www.cdc.gov/statesystem/factsheets/ecigarette/EcigSFIA.html.

8. CDC: weighting BRFSS data . (2017). Accessed: February 10, 2020: https://www.cdc.gov/brfss/annual_data/2017/pdf/weighting-2017-508.pdf.

9. CDC: weighting BRFSS data. (2018). Accessed: February 10, 2020: https://www.cdc.gov/brfss/annual_data/2018/pdf/weighting-2018-508.pdf.

10. Kuehn B: Evaluating e-cigarette lung disease. JAMA. 2019, 322:2162-2162. 10.1001/jama.2019.19637

11. Parekh T, Owens C, Fay K, Phillips J, Kitsantas P: Use of e-cigarettes by women of childbearing age and development of respiratory conditions. South Med J. 2020, 113. 10.14423/SMJ.0000000000001158

12. CDC: e-cigarette use among youth and young adults: a report of the surgeon general . (2016). Accessed: March 14, 2020: https://www.cdc.gov/tobacco/data_statistics/sgr/ecigarettes/pdfs/2016_sgr_entire_report_508.pdf.

13. Jun J, Kim JK: Do state regulations on e-cigarettes have impacts on the e-cigarette prevalence? . Tob Control. 2020, 10.1136/tobaccocontrol-2019-055287 